Popular Religion in Germany and Central Europe, 1400-1800 


\section{THEMES IN FOCUS}

Published titles

Jonathan Barry and Christopher Brooks

THE MIDDLING SORT OF PEOPLE: Culture, Society and

Politics in England, 1500-1800

Christopher Durston and Jacqueline Eales

THE CULTURE OF ENGLISH PURITANISM, 1560-1700

Paul Griffiths, Adam Fox and Steve Hindle

THE EXPERIENCE OF AUTHORITY IN EARLY MODERN

ENGLAND

Tim Harris

POPULAR CULTURE IN ENGLAND, c. 1500-1850

Roy Porter and Marie Mulvey Roberts

PLEASURE IN THE EIGHTEENTH CENTURY

Bob Scribner and Trevor Johnson

POPULAR RELIGION IN GERMANY AND CENTRAL EUROPE, 1400-1800

Forthcoming

Patrick Collinson and John Craig

THE REFORMATION IN ENGLISH TOWNS, 1500-1640 


\title{
Popular Religion in Germany and Central Europe, 1400-1800
}

\author{
Edited by
}

BOB SCRIBNER and TREVOR JOHNSON 
Editorial matter and Introduction ㅇ Bob Scribner and Trevor Johnson; Chapter 1 @ Ulinka Rublack; Chapter 2 @ Thomas A. Fudge; Chapter 3 ๑ J. M. Minty; Chapter 4 ๑ Eric Wilson; Chapter 5 @ Alison Rowlands; Chapter 6 @ C. Scott Dixon; Chapter 7 @ J. C. Wolfart; Chapter 8 (c) Jürgen Beyer, Chapter 9 @ Trevor Johnson, 1996

All rights reserved. No reproduction, copy or transmission of this publication may be made without written permission.

No paragraph of this publication may be reproduced, copied or transmitted save with written permission or in accordance with the provisions of the Copyright, Designs and Patents Act 1988, or under the terms of any licence permitting limited copying issued by the Copyright Licensing Agency, 90 Tottenham Court Road, London W1P 9HE.

Any person who does any unauthorised act in relation to this publication may be liable to criminal prosecution and civil claims for damages.

First published 1996 by

MACMILLAN PRESS LTD

Houndmills, Basingstoke, Hampshire RG21 6XS

and London

Companies and representatives

throughout the world

ISBN 978-0-333-61457-0 ISBN 978-1-349-24836-0 (eBook)

DOI 10.1007/978-1-349-24836-0

A catalogue record for this book is available from the British Library.

$\begin{array}{llllllllll}10 & 9 & 8 & 7 & 6 & 5 & 4 & 3 & 2 & 1\end{array}$

$\begin{array}{llllllllll}05 & 04 & 03 & 02 & 01 & 00 & 99 & 98 & 97 & 96\end{array}$

Published in the United States of America 1996 by

ST. MARTIN'S PRESS, INC.,

Scholarly and Reference Division

175 Fifth Avenue, New York, N.Y. 10010

ISBN 978-0-312-12837-1 


\section{Contents}

List of Illustrations

vii

Introduction

BOB SCRIBNER

1 Female Spirituality and the Infant Jesus in Late Medieval Dominican Convents

ULINKA RUBLACK

2 The 'Crown' and the 'Red Gown': Hussite Popular Religion

THOMAS A. FUDGE

3 Judengasse to Christian Quarter: The Phenomenon of the Converted Synagogue in the Late Medieval and Early Modern Holy Roman Empire

J. M. MINTY

4 Institoris at Innsbruck: Heinrich Institoris, the Summis Desiderantes and the Brixen Witch-Trial of 1485 ERIC WILSON

5 Witchcraft and Popular Religion in Early Modern Rothenburg ob der Tauber ALISON ROWLANDS

6 Popular Beliefs and the Reformation in Brandenburg-Ansbach

C. SCOTT DIXON

7 Why was Private Confession so Contentious in Early Seventeenth-Century Lindau?

J. C. WOLFART 
8 A Lübeck Prophet in Local and Lutheran Context JÜRGEN BEYER

9 Blood, Tears and Xavier-Water: Jesuit Missionaries and Popular Religion in the Eighteenth-Century Upper Palatinate TREVOR JOHNSON

Bibliography

Notes and References 208

Notes on Contributors 276

Index 


\section{List of Illustrations}

1 The Dominican mystic Margaretha von Ebner's infant Jesus doll, carved in Vienna in 1344, now in the Bavarian convent of Maria-Medingen (photograph by Gisela Ott)

2 Albrecht Altdorfer, 'View of Entrance Hall of Regensburg Synagogue', etching 1519 (reproduced courtesy of Hamburger Kunsthalle, Kupferstichkabinett)

3 Albrecht Altdorfer, 'View of Interior of Regensburg Synagogue', etching 1519 (reproduced courtesy of the Museum of Regensburg)

4 Topographical reconstruction of Regensburg, c.1519, showing the destroyed Judengasse and synagogue (reproduced courtesy of Artemis Verlag, Zurich)

5 Michael Ostendorfer, "The Old Church of the Schöne Maria, Regensburg', woodcut, c.1520 (reproduced courtesy of Hacker Books, New York)

6 Michael Ostendorfer, 'The New Church of the Schöne Maria, Regensburg', woodcut, c.1520, after design by Hans Hieber (reproduced courtesy of Hacker Books, New York)

7 Topographical reconstruction of the mid-fourteenth century Nuremberg Judengasse by Karl Kohn (reproduced courtesy of Verein für Geschichte der Stadt Nurnberg) 
8 Lorenz Strauch, 'Earliest Panoramic View of the Hauptmarkt, Nuremberg', oil on panel, c.1599 (reproduced courtesy of Industrie- und Handelskammer, Nümberg)

9 Topographical reconstruction of Cologne, $c .1180$ as determined by Junghanns (reproduced courtesy of Artemis Verlag, Zurich)

10 Topographical reconstruction of medieval Cologne Judengasse as determined by $\mathrm{O}$. Doppelfeld, 1958, ink drawing (1980) by G. Grosch (reproduced courtesy of Kölnisches Stadtmuseum)

11 View of the Town Hall and St Maria in Ieruslame (Ratskapelle), Cologne, lithograph by A. Wünsch as published by Weyer, 1827 (reproduced courtesy of Archiv, Cologne)

12 View of St Maria in Ieruslame (Ratskapelle), Cologne, coloured ink drawing (c.1870) by W. Grohs (reproduced courtesy of Rheinisches Archiv, Cologne) 